\title{
Swimming: I
}

\author{
SYDNEY OLIVIER
}

From a letter by Lord Olivier to Archibald Henderson, 9 June 1913, in Henderson, Bernard Shaw, Playboy and Prophet (London and New York: D. Appleton, 1932) p. 707. Olivier and Shaw attended the Zurich Socialist Congress early in August 1893, Shaw reporting on it for the Star.

Shaw was, and I believe still is, an insatiable swimmer. On our journey together to Zürich in 1893, as delegates to the International Social Congress, after we had battled before breakfast with the rushing flood of the frigid Rhine at Basel, he insisted during our next halt at Bern on committing our bodies to the still more impetuous Aar, with a speed of about five miles an hour and a temperature of about forty degrees in its turbid snow-waters. At Zürich, the lake was more than tepid. So incandescent however was the temperature of the Congress room, that when (as Morley Roberts, who was there with us, reminded me the other day when we met again in Jamaica ${ }^{1}$ ), we used to rush, in the lunch interval, to the bathing house, the water seemed agreeably bracing. Shaw maintained that the lake used to hiss and boil as our red hot bodies plunged into it.

\section{NOTE}

1. Morley Roberts (1857-1942) was a widely travelled journalist and novelist. Olivier had been in Jamaica in 1929-30 as chairman of the West Indian Sugar Commission.

\section{Swimming: II}

\section{ROBERT LORAINE}

From Winifred Loraine, Robert Loraine: Soldier, Actor, Airman (London: Collins, 